\title{
Efficacy and safety of once-daily aclidinium in chronic obstructive pulmonary disease
}

\author{
Paul W Jones ${ }^{1 *}$, Stephen I Rennard ${ }^{2}$, Alvar Agusti ${ }^{3}$, Pascal Chanez ${ }^{4}$, Helgo Magnussen $^{5}$, Leonardo Fabbri ${ }^{6}$, \\ James F Donohue ${ }^{7}$, Eric D Bateman ${ }^{8}$, Nicholas J Gross ${ }^{9}$, Rosa Lamarca ${ }^{10}$, Cynthia Caracta ${ }^{11}$ and Esther Garcia Gil ${ }^{10}$
}

\begin{abstract}
Background: The long-term efficacy and safety of aclidinium bromide, a novel, long-acting muscarinic antagonist, were investigated in patients with moderate to severe chronic obstructive pulmonary disease (COPD).

Methods: In two double-blind, 52-week studies, ACCLAIM/COPD I $(n=843)$ and II $(n=804)$, patients were randomised to inhaled aclidinium $200 \mu \mathrm{g}$ or placebo once-daily. Patients were required to have a postbronchodilator forced expiratory volume in 1 second $\left(\mathrm{FEV}_{1}\right) /$ forced vital capacity ratio of $\leq 70 \%$ and $\mathrm{FEV}_{1}<80 \%$ of the predicted value. The primary endpoint was trough $\mathrm{FEV}_{1}$ at 12 and 28 weeks. Secondary endpoints were health status measured by St George's Respiratory Questionnaire (SGRQ) and time to first moderate or severe COPD exacerbation.

Results: At 12 and 28 weeks, aclidinium improved trough $\mathrm{FEV}_{1}$ versus placebo in ACCLAIM/COPD I (by 61 and $67 \mathrm{~mL}$; both $p<0.001$ ) and ACCLAIM/COPD II (by 63 and $59 \mathrm{~mL}$; both $p<0.001$ ). More patients had a SGRQ improvement $\geq 4$ units at 52 weeks with aclidinium versus placebo in ACCLAIM/COPD I (48.1\% versus 39.5\%; $p=0.025$ ) and ACCLAIM/ COPD II (39.0\% versus 32.8\%; $p=0.074)$. The time to first exacerbation was significantly delayed by aclidinium in ACCLAIM/COPD II (hazard ratio [HR] 0.7; 95\% confidence interval [CI] 0.55 to 0.92; $p=0.01$ ), but not ACCLAIM/COPD I (HR 1.0; $95 \% \mathrm{Cl} 0.72$ to $1.33 ; \mathrm{p}=0.9$ ). Adverse events were minor in both studies.
\end{abstract}

Conclusion: Aclidinium is effective and well tolerated in patients with moderate to severe COPD.

Trial registration: ClinicalTrials.gov: NCT00363896 (ACCLAIM/COPD I) and NCT00358436 (ACCLAIM/COPD II).

Keywords: Aclidinium bromide anticholinergic, chronic obstructive pulmonary disease, long-acting muscarinic antagonist

\section{Background}

Vagal cholinergic tone is the major reversible contributor to airway narrowing in chronic obstructive pulmonary disease (COPD); therefore, inhaled anticholinergic agents play a key role in the treatment of this disorder [1]. The Global Initiative for Chronic Obstructive Lung Disease (GOLD) recommends long-acting bronchodilators for the management of patients with stable COPD [2]; however, only one long-acting anticholinergic agent, tiotropium bromide, is available to date. Given the variability in individual patient responses to therapy in terms of efficacy and tolerability, and individual patient preferences for different formulations and delivery devices, the

\footnotetext{
* Correspondence: pjones@sgul.ac.uk

'St George's, University of London, London, UK

Full list of author information is available at the end of the article
}

investigation of additional long-acting anticholinergic treatment options is warranted.

Aclidinium bromide is a novel, long-acting muscarinic antagonist currently in development for the treatment of COPD. Early studies in preclinical models indicated that aclidinium had potent bronchodilatory effects [3] and an inhibitory effect on mucus hypersecretion [4]. Preclinical and clinical studies have demonstrated the rapid hydrolysis of aclidinium in human plasma into inactive metabolites $[5,6]$, suggesting a reduced propensity for systemic side effects. In Phase II studies, aclidinium showed long-lasting bronchodilatory activity and good tolerability with a low incidence of cardiovascular side effects $[7,8]$.

This paper reports data from two Phase III studies, ACCLAIM/COPD (AClidinium CLinical trial Assessing efficacy and safety In Moderate to severe COPD patients) I and II, to assess the long-term efficacy and safety of
Ciomed Central

C 2011 Jones et al; licensee BioMed Central Ltd. This is an Open Access article distributed under the terms of the Creative Commons Attribution License (http://creativecommons.org/licenses/by/2.0), which permits unrestricted use, distribution, and reproduction in any medium, provided the original work is properly cited. 
once-daily aclidinium $200 \mu \mathrm{g}$ in patients with moderate to severe COPD.

\section{Methods \\ Subjects}

Male and non-pregnant, non-lactating female patients aged $\geq 40$ years were included if they had a diagnosis of COPD according to GOLD criteria [2], with a postbronchodilator forced expiratory volume in 1 second $\left(\mathrm{FEV}_{1}\right) /$ forced vital capacity (FVC) ratio of $\leq 70 \%$ and $\mathrm{FEV}_{1}<80 \%$ of the predicted value [9]. The pre-dose $\mathrm{FEV}_{1}$ at randomisation had to be within $80-120 \%$ of the pre-bronchodilator $\mathrm{FEV}_{1}$ at screening. All patients were current or previous cigarette smokers with a smoking history of $\geq 10$ pack-years. A previous history of exacerbations was not required.

Key exclusion criteria were: history or current diagnosis of asthma, allergic rhinitis or atopy; blood eosinophil count $>600 \mathrm{cell} / \mathrm{mm}^{3}$; respiratory tract infection or COPD exacerbation within 6 weeks prior to screening or during the run-in period; hospitalisation for an acute COPD exacerbation within 3 months prior to screening; use of long-term oxygen therapy; clinically significant respiratory diseases other than COPD; unstable cardiac conditions.

Inhaled salbutamol was permitted on an as-needed basis, but had to be discontinued 6 hours prior to and during a study visit. The following concomitant COPD medications were allowed, provided their administration had been stable for at least 4 weeks prior to screening: inhaled corticosteroids or oral sustained-release theophyllines; oral or parenteral corticosteroids at maximal doses equivalent to $10 \mathrm{mg} /$ day of prednisone or $20 \mathrm{mg}$ every other day; oxygen therapy ( $<15$ hours per day).

The studies were performed in accordance with the Declaration of Helsinki, International Conference on Harmonisation Good Clinical Practice Guidelines and local regulations. Prior to study initiation at each centre, the protocol was approved by an Independent Ethics Committee or Institutional Review Board. All patients gave written informed consent. The studies were registered with ClinicalTrials.gov as follows: NCT00363896 (ACCLAIM/ COPD I) and NCT00358436 (ACCLAIM/COPD II).

\section{Study design}

Two identical 52-week, double-blind, randomised, placebo-controlled, parallel-group studies were performed as regulatory organisations require replicated data. ACCLAIM/COPD I was conducted at 139 centres in 16 European countries and ACCLAIM/COPD II at 119 sites in 7 countries (primarily in North America). After screening, patients underwent a 14-day run-in period to assess their disease stability. Eligible patients were randomised in a 3:1 ratio to receive aclidinium $200 \mu \mathrm{g}$ or matching placebo once-daily via the Genuair ${ }^{\circledR}$ inhaler, a novel multidose dry powder inhaler [10].

It was estimated that a total sample size of 820 patients per study (615 and 205 patients in the aclidinium and placebo arms, respectively) would provide at least $90 \%$ power to detect a difference of $100 \mathrm{~mL}$ in trough $\mathrm{FEV}_{1}$ between the two arms at 12 and 28 weeks, with a twosided 5\% level of significance and assuming a standard deviation of $310 \mathrm{~mL}$ [7].

\section{Assessments}

Spirometry was conducted according to American Thoracic Society (ATS)/European Respiratory Society (ERS) recommendations [11] at 1 hour pre-dose and immediately before dosing during study visits on Day 1 (baseline); Day 2; Week 1; every month up to Week 20; and thereafter every 2 months until Week 52 . Measurements were also performed at $0.25,0.5,1,2$ and 3 hours post-dose on Day 1 ; and at 0.5, 1, 2 and 3 hours post-dose at Weeks 1, 4, 8, $12,28,44$ and 52 . Sites were provided with identical spirometry equipment, a detailed study manual and training. A centralised quality-assurance review of all spirometry data was conducted throughout the study. The spirometry data were electronically transmitted to a data-management centre where an independent, blinded, spirometric expert reviewed the acceptability and repeatability of the data according to ATS/ERS acceptability criteria.

Health status and dyspnoea were evaluated pre-dose on Day 1 (baseline) and at Weeks 12, 28, 44 and 52 using the St George's Respiratory Questionnaire (SGRQ; self administered) and Baseline/Transitional Dyspnoea Index (BDI/TDI; administered by an independent reviewer).

Data on morning and evening peak expiratory flow, COPD symptoms over 24 hours (breathlessness on a scale of 0 to 4; cough, sputum production and wheezing on a scale of 0 to 3 ), use of daily rescue medication and concomitant medication were recorded in the patient's diary and reviewed by the investigator at each visit to identify the occurrence of a COPD exacerbation. COPD exacerbations were defined as an increase in COPD symptoms over at least two consecutive days, associated with increased use of bronchodilators (mild exacerbation), treatment with antibiotics and/or systemic corticosteroids (moderate exacerbation) or leading to hospitalisation (severe exacerbation).

Safety was assessed by adverse-event (AE) monitoring, physical examination, blood pressure, 12-lead electrocardiogram (ECG) and laboratory data (haematology, biochemistry and urinalysis).

\section{Statistical analysis}

Efficacy analyses were performed on the intent-to-treat population, defined as all randomised patients who received at least one dose of study medication and who had a baseline and at least one post-baseline trough $\mathrm{FEV}_{1}$ 
measurement. The safety population consisted of all randomised patients who received at least one dose of study medication.

$\mathrm{FEV}_{1}, \mathrm{FVC}$, inspiratory capacity, peak expiratory flow and change from baseline in SGRQ scores were analysed using an analysis of covariance (ANCOVA) model with treatment and sex as factors, and baseline values and age as covariates; the same model, without adjustment for age and sex, was used to analyse the change from baseline in dyspnoea, COPD symptom scores and use of daily rescue medication. Missing data were imputed using a last observation carried forward approach. The minimal clinically important difference (MCID) for the SGRQ and TDI is 4 units and 1 unit, respectively $[12,13]$. A logistic regression model was used to analyse the number of patients with a $\geq 4$-unit decrease in SGRQ total score (with adjustment for age, sex and baseline values) and a $\geq 1$-unit improvement in TDI total score (with adjustment for baseline values). Time to first moderate or severe COPD exacerbation was evaluated using a Cox Proportional Hazards model adjusted for age, sex and COPD severity at screening.

The primary endpoint was trough $\mathrm{FEV}_{1}$ at Weeks 12 and 28 to fulfil US and European regulatory requirements, respectively. Secondary endpoints were: the number of patients who achieved a clinically relevant improvement in health-related quality of life at 52 weeks, as measured by a $\geq 4$-unit decrease from baseline on the SGRQ total score; and time to first moderate or severe COPD exacerbation.

\section{Results}

\section{Study population}

Patient disposition in the two studies is illustrated in Figure 1. Table 1 shows demographics and disease status at baseline. Compared with ACCLAIM/COPD I, in ACCLAIM/COPD II, there were slightly more females and fewer smokers, the post-bronchodilator $\mathrm{FEV}_{1}$ was slightly lower and the bronchodilator reversibility was slightly higher. The percentage of patients who continued to use inhaled corticosteroids in the aclidinium and placebo groups was $39.1 \%$ and $40.0 \%$, respectively, in ACCLAIM/COPD I, and $40.2 \%$ and $44.3 \%$, respectively, in ACCLAIM/COPD II. In both studies, a lower proportion of patients discontinued treatment in the aclidinium arm compared with the placebo arm; the difference in withdrawal rates between the study arms was greater in ACCLAIM/COPD II (25.7\% versus $42.2 \%$, respectively; $16.5 \%$ difference) than in ACCLAIM/COPD I (14.2\% versus $21.8 \%$, respectively; $7.6 \%$ difference).

\section{Efficacy}

\section{Lung function}

At Weeks 12 and 28, aclidinium improved the baselineadjusted mean trough $\mathrm{FEV}_{1}$ compared with placebo in

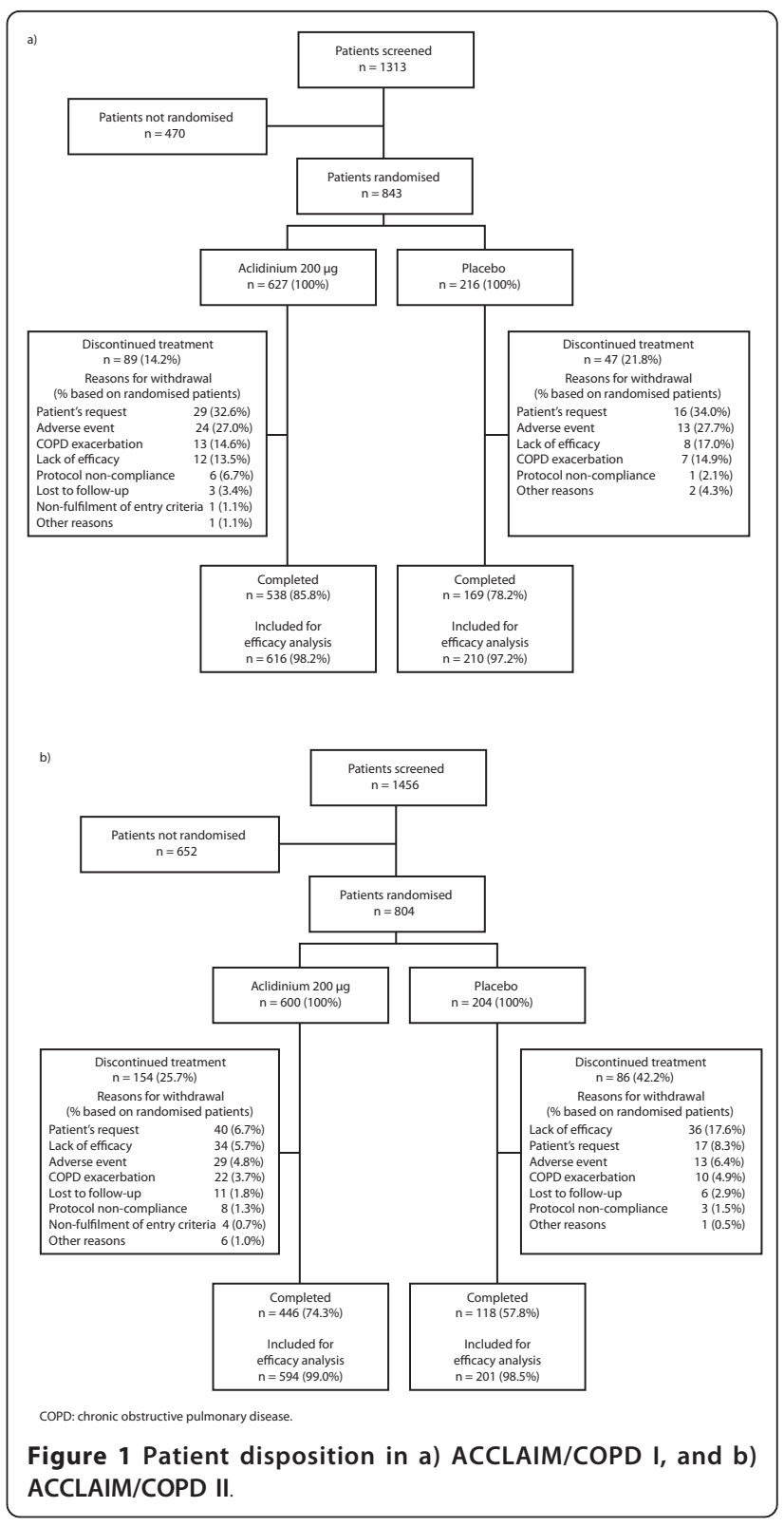

ACCLAIM/COPD I (by 61 and $67 \mathrm{~mL}$, respectively; both $\mathrm{p}<0.001$ ) and ACCLAIM/COPD II (by 63 and $59 \mathrm{~mL}$, respectively; both $\mathrm{p}<0.001)$. In both studies, this effect was maintained over the 52-week study period (Figure 2; Table 2). In ACCLAIM/COPD I, treatment differences in trough $\mathrm{FEV}_{1}$ ranged from 60 to $67 \mathrm{~mL}$ at all time points except for Weeks 1 and 4 where the differences were 44 and $37 \mathrm{~mL}$, respectively ( $\mathrm{p}$-values ranged from 0.021 to $<0.0001)$. In ACCLAIM/COPD II, treatment differences ranged from 51 to $78 \mathrm{~mL}$ throughout the study (p-values ranged from 0.0011 to $<0.0001$ ).

Significant improvements in other lung function parameters were observed for aclidinium versus placebo throughout the two studies (Table 2). In both studies, 


\begin{tabular}{|c|c|c|c|c|}
\hline & ACCLAIM/C & PPD I & ACCLAIM/CC & PPD II \\
\hline & $\begin{array}{c}\text { Aclidinium } 200 \mu \mathrm{g} \\
(\mathrm{n}=627)\end{array}$ & $\begin{array}{l}\text { Placebo } \\
(\mathrm{n}=216)\end{array}$ & $\begin{array}{c}\text { Aclidinium } 200 \mu g \\
(n=600)\end{array}$ & $\begin{array}{l}\text { Placebo } \\
(n=204)\end{array}$ \\
\hline Age, mean $(S D)$ years & $62.6(8.2)$ & $61.9(8.3)$ & $65.1(8.6)$ & $65.2(8.6)$ \\
\hline Male, n (\%) & $488(77.8)$ & $175(81.0)$ & $383(63.8)$ & $124(60.8)$ \\
\hline Caucasian, n (\%) & $627(100.0)$ & $215(99.5)$ & $552(92.0)$ & $189(92.7)$ \\
\hline BMl, mean (SD), $\mathrm{kg} / \mathrm{m}^{2}$ & $26.4(4.70)$ & $26.7(4.65)$ & $26.8(5.9)$ & $26.6(6.1)$ \\
\hline Current smoker, n (\%) & $283(45.1)$ & $98(45.4)$ & $222(37.0)$ & $79(38.7)$ \\
\hline Smoking history, mean (SD) pack-years & $40.4(21.0)$ & $38.4(18.3)$ & $57.8(29.9)$ & $58.2(28.4)$ \\
\hline Post-bronchodilator $\mathrm{FEV}_{1}$, mean (SD) \% of predicted value & $54.2(15.1)$ & $52.9(15.2)$ & $50.6(15.6)$ & $49.4(15.1)$ \\
\hline Post-bronchodilator $\mathrm{FEV}_{1} / \mathrm{FVC}$ ratio, mean (SD) \% & $49.2(11.4)$ & $48.9(11.1)$ & $48.0(11.7)$ & $47.1(11.9)$ \\
\hline Bronchodilator reversibility, mean (SD) \% & $12.3(14.2)$ & $12.9(14.0)$ & $17.7(15.7)$ & $17.3(13.5)$ \\
\hline Pre-dose $\mathrm{FEV}_{1}$ on Day 1 , mean (SD) L & $1.413(0.514)$ & $1.385(0.509)$ & $1.214(0.489)$ & $1.154(0.479)$ \\
\hline SGRQ total score, mean (SD) & $47.3(17.6)$ & $47.3(18.0)$ & $45.2(16.8)$ & $47.1(16.3)$ \\
\hline Baseline Dyspnoea Index focal score, mean (SD) & $6.3(2.2)$ & $6.4(2.2)$ & $6.5(2.3)$ & $6.2(2.3)$ \\
\hline Pre-study COPD medication, $\mathrm{n}(\%)$ & $532(84.9)$ & $178(82.4)$ & $505(84.2)$ & $177(86.8)$ \\
\hline Inhaled corticosteroids & $239(38.1)$ & $83(38.4)$ & $228(38.0)$ & $78(38.2)$ \\
\hline Long-acting $\beta_{2}$-agonists & $99(15.8)$ & $34(15.7)$ & $38(6.3)$ & $14(16.9)$ \\
\hline Long-acting $\beta_{2}$-agonists + inhaled corticosteroids* & $170(27.1)$ & $47(21.8)$ & $217(36.2)$ & $76(27.3)$ \\
\hline Long-acting muscarinic antagonist & $110(17.5)$ & $39(18.1)$ & $103(17.2)$ & $37(18.1)$ \\
\hline Short-acting $\beta_{2}$-agonists & $331(52.8)$ & $95(44.0)$ & $408(68.0)$ & $143(70.1)$ \\
\hline Short-acting $\beta_{2}$-agonists + short-acting muscarinic agents & $98(15.6)$ & $45(20.8)$ & $55(9.2)$ & $25(12.3)$ \\
\hline Short-acting muscarinic agents & $99(15.8)$ & $26(12.0)$ & $51(8.5)$ & $28(13.7)$ \\
\hline Xanthines & $116(18.5)$ & $34(15.7)$ & $29(4.8)$ & $6(2.9)$ \\
\hline Patients with $\geq 1$ self-reported COPD exacerbation in previous year, $\mathrm{n}(\%)^{\dagger}$ & $354(56.5)$ & 131 (60.6) & $182(30.3)$ & $64(31.4)$ \\
\hline
\end{tabular}

*The percentages of patients who received long-acting $\beta_{2}$-agonists plus inhaled corticosteroids include those who switched from long-acting $\beta_{2}$-agonists plus inhaled corticosteroids to inhaled corticosteroids prior to screening.

${ }^{\dagger}$ Data missing for four patients in ACCLAIM/COPD I (two each in the aclidinium and placebo arms).

BMI: body mass index; COPD: chronic obstructive pulmonary disease; FEV ${ }_{1}$ forced expiratory volume in 1 second; FVC: forced vital capacity; SGRQ: St George's Respiratory Index; SD: standard deviation.

the median time to peak $\mathrm{FEV}_{1}$ in the aclidinium group was 2 hours and significantly more patients had an increase in $\mathrm{FEV}_{1}$ of $\geq 15 \%$ above baseline at $0.25,0.5,1$, 2 and 3 hours post-dose with aclidinium compared with placebo ( $\mathrm{p}<0.0001$ at each time point).

An exploratory post-hoc analysis using pooled data from the two studies was conducted to examine the treatment

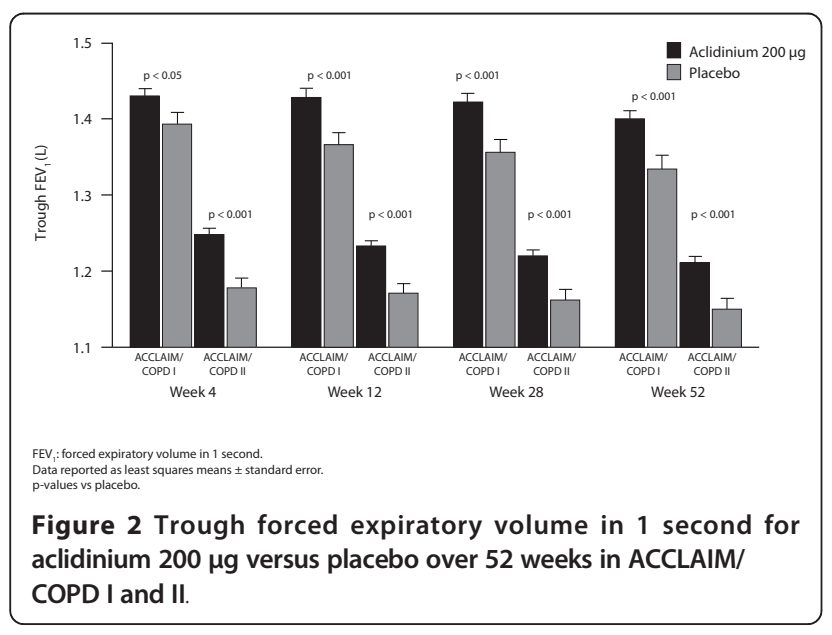

differences in trough $\mathrm{FEV}_{1}$ when the patient population was stratified according to the use of concomitant inhaled corticosteroids. The magnitude of improvement in trough $\mathrm{FEV}_{1}$ with aclidinium over placebo was slightly greater in

Table 2 Baseline-adjusted mean differences between aclidinium and placebo on lung function parameters at all measured time points throughout the 52-week studies

\begin{tabular}{lcc}
\hline Parameter & ACCLAIM/COPD I & ACCLAIM/COPD II \\
\hline Trough FEV, $\mathrm{mL}$ & $37-67^{*}$ & $51-78^{\S}$ \\
Peak FEV $_{1}, \mathrm{~mL}$ & $147-177^{\ddagger}$ & $141-156^{\ddagger}$ \\
AUC $\left._{(0-3} \mathrm{h}\right), \mathrm{mL}$ & $135-166^{\ddagger}$ & $133-150^{\ddagger}$ \\
Trough FVC, mL & $96-141^{\S}$ & $83-148^{\dagger}$ \\
Peak FVC, mL & $275-310^{\ddagger}$ & $259-315^{\ddagger}$ \\
Trough IC, mL & $58-101^{*}$ & $64-135^{\S}$ \\
Peak IC, $\mathrm{mL}$ & $166-204^{\ddagger}$ & $171-220^{\ddagger}$ \\
Morning PEF, mL/min & $6.1-13.9^{*}$ & $9.8-17.2^{*}$ \\
Evening PEF, mL/min & $18.9-22.8^{\ddagger}$ & $16.9-22.9^{\S}$ \\
\hline
\end{tabular}

${ }^{*} \mathrm{p}<0.05 ;{ }^{5} \mathrm{p}<0.01 ;{ }^{\dagger} \mathrm{p}<0.001 ;{ }^{\ddagger} \mathrm{p}<0.0001$.

Data are reported as the minimum and maximum values over the treatment period; the indicated $p$-values apply throughout the stated range.

$\mathrm{FEV}_{1}$ : forced expiratory volume in 1 second; $\mathrm{AUC}_{(0-3 \mathrm{~h})}$ : area under the curve from 0 to $3 \mathrm{~h}$ post-dose; FVC: forced vital capacity; IC: inspiratory capacity; PEF: peak expiratory flow. 
patients who used inhaled corticosteroids compared with those who did not at Weeks 4 (64 versus $47 \mathrm{~mL}$ ), 44 (80 versus $48 \mathrm{~mL}$ ) and 52 (90 versus $48 \mathrm{~mL}$ ). However, treatment differences in trough $\mathrm{FEV}_{1}$ were slightly lower or similar in patients who used inhaled corticosteroids compared with those who did not at Weeks 12 (52 versus $68 \mathrm{~mL}$ ) and 28 (65 versus $63 \mathrm{~mL}$ ).

\section{Quality of life and dyspnoea}

In ACCLAIM/COPD I, significantly more patients receiving aclidinium had an improvement in SGRQ total score $\geq 4$ units compared with placebo at all measured time points; at 52 weeks, the percentage of patients achieving this improvement was $48.1 \%$ versus $39.5 \%$ for aclidinium versus placebo, respectively ( $p=0.025$; Figure 3 ). In ACCLAIM/COPD II, significantly more patients had an improvement in SGRQ total score $\geq 4$ units with aclidinium versus placebo up to 44 weeks; at 52 weeks, the percentage of patients achieving this improvement was $39.0 \%$ versus $32.8 \%$ for aclidinium versus placebo, respectively ( $\mathrm{p}=0.074$; Figure 3). At Week 52, the mean improvement from baseline in SGRQ total score was greater for aclidinium compared with placebo in ACCLAIM/COPD I (-4.63 versus -3.10 , respectively; treatment difference 1.53 ; $\mathrm{p}=0.19)$ and ACCLAIM/COPD II (-3.49 versus -1.28, respectively; treatment difference $2.21 ; \mathrm{p}=0.021)$. Greater improvements in baseline-adjusted SGRQ total score were observed for aclidinium versus placebo throughout both ACCLAIM/COPD I (range 1.53-2.71; p < 0.05 at Weeks 12 and 28) and ACCLAIM/COPD II (range 2.21-3.54; $\mathrm{p}<$ 0.05 at all time points).

In ACCLAIM/COPD I, more patients receiving aclidinium versus placebo exceeded the MCID for TDI focal score at 52 weeks ( $56.4 \%$ versus $38.0 \%$; odds ratio 2.22 ; 95\% confidence interval [CI] 1.57 to 3.13 ; p < 0.0001); similar results were observed at Weeks 12, 28 and 44 .

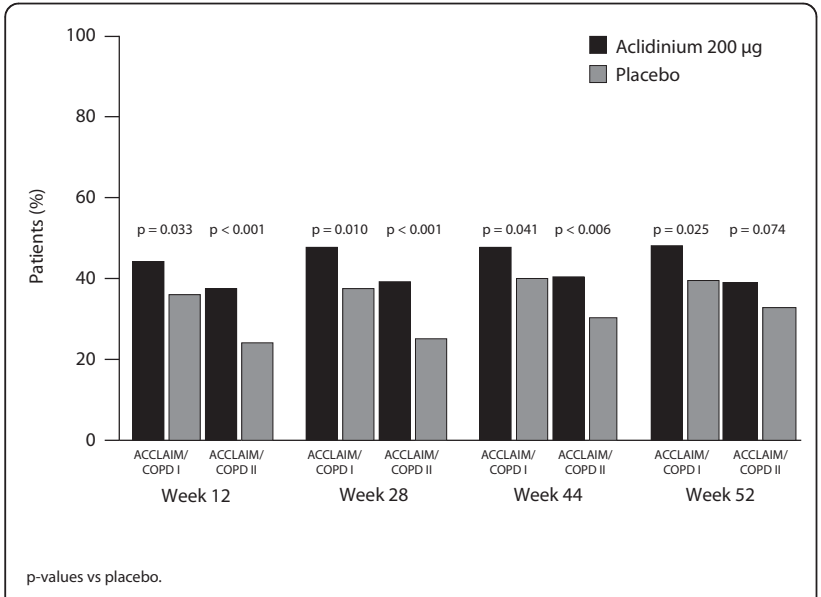

Figure 3 Percentage of patients with a clinically relevant improvement in St George's Respiratory Questionnaire total score ( $\geq 4$ units) over time in ACCLAIM/COPD I and II.
The proportion of patients who exceeded the MCID was also greater for aclidinium versus placebo at all time points in ACCLAIM/COPD II, but was significant only at Week 12 (53.1\% versus 42.7\%; odds ratio 1.53 ; 95\% CI 1.04 to $2.23 ; \mathrm{p}=0.029)$. At Week 52 , the mean improvement from baseline in TDI focal score was greater for aclidinium compared with placebo in ACCLAIM/COPD I (1.83 versus 0.61 ; treatment difference $1.22 ; \mathrm{p}<0.0001$ ) and ACCLAIM/COPD II (1.61 versus 1.09; treatment difference 0.52; $\mathrm{p}=0.12$ ). Baseline-adjusted mean treatment differences in TDI focal score favoured aclidinium throughout the study in ACCLAIM/COPD I (range 0.731.22; $\mathrm{p}<0.01$ at all time points) and ACCLAIM/COPD II (range 0.52-1.03; p < 0.01 at Weeks 12, 28 and 44).

\section{Exacerbations}

The rate of moderate or severe exacerbations in the placebo arm was numerically lower in ACCLAIM/COPD I (0.46 events/patient/year, respectively) than in ACCLAIM/ COPD II (0.80 events/patient/year, respectively). In ACCLAIM/COPD I, the proportion of patients who experienced a moderate or severe exacerbation was similar in the aclidinium and placebo groups (26.6\% versus $25.7 \%$, respectively). There was no significant difference between the two groups in time to first moderate or severe exacerbation (hazard ratio $1.0 ; 95 \%$ CI 0.72 to 1.33 ; $\mathrm{p}=0.9$; Figure 4). In ACCLAIM/COPD II, fewer patients in the aclidinium group experienced a moderate or severe exacerbation compared with those in the placebo group (33.2\% versus $39.8 \%$, respectively; rate ratio 0.7 ; $95 \% \mathrm{CI}$ 0.55 to $0.90 ; \mathrm{p}=0.0046)$. Aclidinium significantly delayed the time to first moderate or severe exacerbation compared with placebo (hazard ratio 0.7 ; $95 \%$ CI 0.55 to 0.92 ; $\mathrm{p}=0.01 ;$ Figure 4).

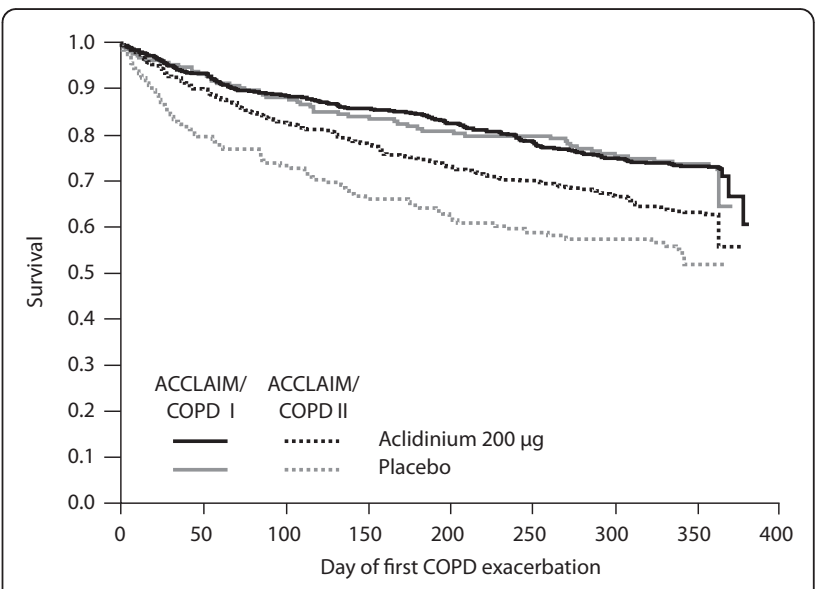

COPD: chronic obstructive pulmonary disease.

Figure 4 Kaplan-Meier survival curves for the time to first moderate or severe chronic obstructive pulmonary disease exacerbation in ACCLAIM/COPD I and II. 


\section{Other efficacy measures}

In ACCLAIM/COPD I, there were no significant differences between aclidinium and placebo in patientrecorded daily symptom scores for breathlessness, cough, sputum production or wheezing, or use of daily rescue medication. However, in ACCLAIM/COPD II, there were significant differences in favour of aclidinium for cough and sputum production (Week 1), breathlessness (Week 12), wheezing (Week 28) and use of daily rescue medication (Weeks 12 and 28) (p < 0.05 for all).

\section{Safety}

The overall incidence of AEs was similar in the aclidinium and placebo groups for ACCLAIM/COPD I and II (Table 3). AEs, most of which were mild to moderate in intensity, were similar between the two groups in both studies. AEs associated with anticholinergic medication occurred with an incidence of $<1 \%$ in both the aclidinium and placebo groups, except for dry mouth $(1.0 \%$ versus $0.9 \%$ respectively) in ACCLAIM/COPD I, and urinary tract infection ( $4.8 \%$ versus $4.9 \%$, respectively), constipation (2.2\% versus $2.0 \%$, respectively) and dry mouth ( $0.3 \%$ versus $1.5 \%$, respectively) in ACCLAIM/ COPD II. AEs reported by $\geq 2 \%$ of patients in either group of either study and possible anticholinergic AEs are provided in Tables 4 and 5 , respectively.

The incidence of serious adverse events (SAEs) was similar for aclidinium and placebo in both studies (Table 3). In ACCLAIM/COPD I, only two patients, both in the aclidinium group, reported SAEs that were considered to be treatment-related (angle closure glaucoma and open angle glaucoma). Six patients in ACCLAIM/COPD II reported treatment-related SAEs, of whom four received aclidinium (atrial fibrillation and sick sinus syndrome, atrial flutter, myocardial infarction and pneumonia) and two received placebo (headache and rash [same patient], and cerebellar infarction). In each study, the percent incidence of deaths was lower in the aclidinium group than in the placebo group (Table 3), and none were considered to be treatment-related.

Cardiac and vascular disorders were reported at a similar frequency in the aclidinium and placebo groups of each study (Table 3). In ACCLAIM/COPD I, only two patients (one in each group) experienced a cerebrovascular accident or ischaemic stroke. Nine patients in ACCLAIM/COPD II reported a cerebrovascular accident, cerebral infarction or transient ischaemic attack, of whom seven (1.2\%) received aclidinium and two (1.0\%) received placebo.

No clinically relevant changes in laboratory parameters, vital signs or ECG results (including QTc intervals) were observed in either group in either study.

\section{Discussion}

These studies show that aclidinium $200 \mu \mathrm{g}$ once-daily improves lung function in patients with moderate to severe COPD. Compared with placebo, aclidinium improved the adjusted mean trough $\mathrm{FEV}_{1}$ by 60 to $67 \mathrm{~mL}$ at all time points after 4 weeks in ACCLAIM/COPD I, and by 51 to $78 \mathrm{~mL}$ throughout the treatment period in ACCLAIM/COPD II. The slight decrease in the trough $\mathrm{FEV}_{1}$ response with aclidinium over time does not appear to be related to tachyphylaxis, as a similar decline occurred with placebo in both studies. There were some small differences in the patient demographics between the studies, perhaps the most relevant being a lower mean bronchodilator reversibility in ACCLAIM/COPD I compared with ACCLAIM/COPD II. Despite this difference, the improvements in trough $\mathrm{FEV}_{1}$ were similar. These trough $\mathrm{FEV}_{1}$ improvements are smaller than those seen in previous studies of aclidinium $200 \mu \mathrm{g}$ [7] and tiotropium [14-20], where the magnitude of improvement ranged from 100 to $150 \mathrm{~mL}$. Interestingly, in the recent UPLIFT trial $(\mathrm{n}=5993)$, reported differences in trough $\mathrm{FEV}_{1}$ between tiotropium and placebo were smaller, ranging from 87 to $103 \mathrm{~mL}$ [21]. In the ACCLAIM/COPD and UPLIFT trials, patients were allowed to use inhaled corticosteroids as concomitant therapy, while in UPLIFT,

Table 3 Adverse-event profile in ACCLAIM/COPD I and II



*System organ classes.

COPD exacerbations were reported as part of the efficacy evaluations and, unless life-threatening, were not considered to be AEs.

AEs: adverse events; COPD: chronic obstructive pulmonary disorder; SAEs: serious adverse events. 
Table 4 Adverse events reported by $\geq 2 \%$ of patients in any treatment group in ACCLAIM/COPD I or ACCLAIM/COPD II

\begin{tabular}{|c|c|c|c|c|}
\hline \multirow[t]{2}{*}{ Adverse event preferred term } & \multicolumn{2}{|c|}{ ACCLAIM/COPD I } & \multicolumn{2}{|c|}{ ACCLAIM/COPD II } \\
\hline & $\begin{array}{c}\text { Aclidinium } 200 \mu \mathrm{g} \\
(\mathrm{n}=627) \\
\mathrm{n}(\%)\end{array}$ & $\begin{array}{c}\text { Placebo } \\
(\mathrm{n}=216) \\
\mathrm{n}(\%)\end{array}$ & $\begin{array}{c}\text { Aclidinium } 200 \mu \mathrm{g} \\
(\mathrm{n}=600) \\
\mathrm{n}(\%)\end{array}$ & $\begin{array}{c}\text { Placebo } \\
(\mathrm{n}=204) \\
\mathrm{n}(\%)\end{array}$ \\
\hline Nasopharyngitis & $102(16.3)$ & $31(14.4)$ & $76(12.7)$ & $23(11.3)$ \\
\hline Headache & $71(11.3)$ & $27(12.5)$ & $85(14.2)$ & $26(12.7)$ \\
\hline Upper respiratory tract infection & $8(1.3)$ & $3(1.4)$ & $65(10.8)$ & $20(9.8)$ \\
\hline Back pain & $30(4.8)$ & $10(4.6)$ & $40(6.7)$ & $15(7.4)$ \\
\hline Diarrhoea & $17(2.7)$ & $1(0.5)$ & $42(7.0)$ & $8(3.9)$ \\
\hline Pharyngolaryngeal pain & $21(3.3)$ & $3(1.4)$ & $25(4.2)$ & $11(5.4)$ \\
\hline Urinary tract infection & $5(0.8)$ & $2(0.9)$ & $29(4.8)$ & $10(4.9)$ \\
\hline Cough & $29(4.6)$ & $8(3.7)$ & $29(4.8)$ & $8(3.9)$ \\
\hline Hypertension & $9(1.4)$ & $9(4.2)$ & $27(4.5)$ & $6(2.9)$ \\
\hline Sinusitis & $5(0.8)$ & $1(0.5)$ & $27(4.5)$ & $9(4.4)$ \\
\hline Dyspnoea & $12(1.9)$ & $5(2.3)$ & $17(2.8)$ & $9(4.4)$ \\
\hline Arthralgia & $17(2.7)$ & $1(0.5)$ & $24(4.0)$ & $5(2.5)$ \\
\hline Influenza & $21(3.3)$ & $4(1.9)$ & $22(3.7)$ & $8(3.9)$ \\
\hline Pain in extremity & $5(0.8)$ & $3(1.4)$ & $23(3.8)$ & $4(2.0)$ \\
\hline Dizziness & $15(2.4)$ & $6(2.8)$ & $19(3.2)$ & $7(3.4)$ \\
\hline Abdominal pain & $6(1.0)$ & $3(1.4)$ & $20(3.3)$ & $0(0.0)$ \\
\hline Muscle spasms & $4(0.6)$ & $0(0.0)$ & $19(3.2)$ & $5(2.5)$ \\
\hline Musculoskeletal pain & $7(1.1)$ & $1(0.5)$ & $19(3.2)$ & $3(1.5)$ \\
\hline Pneumonia & $12(1.9)$ & $7(3.2)$ & $10(1.7)$ & $4(2.0)$ \\
\hline Rhinitis & $12(1.9)$ & $7(3.2)$ & $14(2.3)$ & $4(2.0)$ \\
\hline Myalgia & $3(0.5)$ & $3(1.4)$ & $18(3.0)$ & $3(1.5)$ \\
\hline Oedema peripheral & $7(1.1)$ & $2(0.9)$ & $18(3.0)$ & $2(1.0)$ \\
\hline Chest pain & $5(0.8)$ & $1(0.5)$ & $10(1.7)$ & $6(2.9)$ \\
\hline Insomnia & $7(1.1)$ & $1(0.5)$ & $8(1.3)$ & $6(2.9)$ \\
\hline Nausea & $8(1.3)$ & $3(1.4)$ & $16(2.7)$ & $6(2.9)$ \\
\hline Viral infection & $9(1.4)$ & $6(2.8)$ & $5(0.8)$ & $3(1.5)$ \\
\hline Bronchitis & $4(0.6)$ & $1(0.5)$ & $10(1.7)$ & $5(2.5)$ \\
\hline Depression & $3(0.5)$ & $3(1.4)$ & $15(2.5)$ & $4(2.0)$ \\
\hline Blood glucose increased & $3(0.5)$ & $4(1.9)$ & $3(0.5)$ & $5(2.5)$ \\
\hline Epistaxis & $5(0.8)$ & $0(0.0)$ & $8(1.3)$ & $5(2.5)$ \\
\hline Neck pain & $7(1.1)$ & $0(0.0)$ & $6(1.0)$ & $5(2.5)$ \\
\hline Procedural pain & $1(0.2)$ & $1(0.5)$ & $5(0.8)$ & $5(2.5)$ \\
\hline Vomiting & $7(1.1)$ & $0(0.0)$ & $15(2.5)$ & $5(2.5)$ \\
\hline Contusion & $11(1.8)$ & $3(1.4)$ & $14(2.3)$ & $1(0.5)$ \\
\hline Rash & $2(0.3)$ & $0(0.0)$ & $14(2.3)$ & $3(1.5)$ \\
\hline Toothache & $12(1.9)$ & $5(2.3)$ & $12(2.0)$ & $2(1.0)$ \\
\hline Constipation & $4(0.6)$ & $0(0.0)$ & $13(2.2)$ & $4(2.0)$ \\
\hline Gamma-glutamyl transferase increased & $13(2.1)$ & $2(0.9)$ & $2(0.3)$ & $3(1.5)$ \\
\hline Angina pectoris & $4(0.6)$ & $3(1.4)$ & $3(0.5)$ & $4(2.0)$ \\
\hline Fatigue & $4(0.6)$ & $1(0.5)$ & $10(1.7)$ & $4(2.0)$ \\
\hline Lower respiratory tract infection & $5(0.8)$ & $0(0.0)$ & $5(0.8)$ & $4(2.0)$ \\
\hline Musculoskeletal chest pain & $7(1.1)$ & $1(0.5)$ & $12(2.0)$ & $4(2.0)$ \\
\hline Pain & $0(0.0)$ & $0(0.0)$ & $6(1.0)$ & $4(2.0)$ \\
\hline Pyrexia & $8(1.3)$ & $3(1.4)$ & $12(2.0)$ & $1(0.5)$ \\
\hline Rhinorrhoea & $2(0.3)$ & $1(0.5)$ & $9(1.5)$ & $4(2.0)$ \\
\hline Syncope & $1(0.2)$ & $0(0.0)$ & $2(0.3)$ & $4(2.0)$ \\
\hline
\end{tabular}


Table 5 Patients with $\geq 2$ possible anticholinergic adverse events in any group in ACCLAIM/COPD I or ACCLAIM/COPD II (by system organ class and preferred term)

\begin{tabular}{|c|c|c|c|c|c|}
\hline \multirow[t]{2}{*}{ System organ class } & \multirow[t]{2}{*}{ Adverse event preferred term } & \multicolumn{2}{|c|}{ ACCLAIM/COPD I } & \multicolumn{2}{|c|}{ ACCLAIM/COPD II } \\
\hline & & $\begin{array}{c}\text { Aclidinium } 200 \mu \mathrm{g} \\
(\mathrm{n}=627) \\
\mathrm{n}(\%)\end{array}$ & $\begin{array}{c}\text { Placebo } \\
(\mathrm{n}=216) \\
\mathrm{n}(\%)\end{array}$ & $\begin{array}{c}\text { Aclidinium } 200 \mu \mathrm{g} \\
(\mathrm{n}=600) \\
\mathrm{n}(\%)\end{array}$ & $\begin{array}{c}\text { Placebo } \\
(\mathrm{n}=204) \\
\mathrm{n}(\%)\end{array}$ \\
\hline & Atrial fibrillation & $3(0.5)$ & $2(0.9)$ & $3(0.5)$ & $0(0.0)$ \\
\hline & Atrial flutter & $0(0.0)$ & $0(0.0)$ & $2(0.3)$ & $1(0.5)$ \\
\hline \multirow[t]{5}{*}{ Cardiac disorders } & Sinus tachycardia & $2(0.3)$ & $1(0.5)$ & $1(0.2)$ & $0(0.0)$ \\
\hline & Tachycardia & $3(0.5)$ & $0(0.0)$ & $3(0.5)$ & $1(0.5)$ \\
\hline & Ventricular extrasystoles & $1(0.2)$ & $1(0.5)$ & $3(0.5)$ & $0(0.0)$ \\
\hline & Dry eye & $1(0.2)$ & $1(0.5)$ & $5(0.8)$ & $0(0.0)$ \\
\hline & Eye irritation & $0(0.0)$ & $0(0.0)$ & $3(0.5)$ & $1(0.5)$ \\
\hline \multirow[t]{3}{*}{ Eye disorders } & Eye pain & $3(0.5)$ & $0(0.0)$ & $0(0.0)$ & $0(0.0)$ \\
\hline & Vision blurred & $0(0.0)$ & $0(0.0)$ & $3(0.5)$ & $1(0.5)$ \\
\hline & Visual acuity reduced & $0(0.0)$ & $0(0.0)$ & $2(0.3)$ & $1(0.5)$ \\
\hline \multirow[t]{2}{*}{ Gastrointestinal disorders } & Constipation & $4(0.6)$ & $0(0.0)$ & $13(2.2)$ & $4(2.0)$ \\
\hline & Dry mouth & $6(1.0)$ & $2(0.9)$ & $2(0.3)$ & $3(1.5)$ \\
\hline Infections and infestations & Urinary tract infection & $0(0.0)$ & $0(0.0)$ & $29(4.8)$ & $10(4.9)$ \\
\hline
\end{tabular}

they could also use long-acting $\beta_{2}$-agonists. The UPLIFT authors speculated that concomitant therapy may have diminished the measured treatment effect [21], and it is possible that a similar effect operated in the ACCLAIM/ COPD trials, although perhaps to a lesser extent, given that long-acting $\beta$-agonists were not permitted in these studies. This hypothesis cannot be tested reliably by a subgroup analysis to compare patients with or without concomitant inhaled corticosteroids, because it is not possible to remove the potential confounding effect of underlying disease severity having influenced the physician's decision to treat with inhaled corticosteroids. Pooled post-hoc analyses of the ACCLAIM/COPD studies suggested that patients who used inhaled corticosteroids during aclidinium treatment showed greater bronchodilation than those who did not, but these differences were not consistent over time.

As $\mathrm{FEV}_{1}$ correlates poorly with health status and COPD symptoms [22], it is important to directly investigate the effects of therapy on these parameters. At all time points in ACCLAIM/COPD I, significantly greater proportions of patients with aclidinium versus placebo exceeded the MCID for SGRQ total score and TDI focal score, and therefore may be considered to have achieved clinically significant improvements in health status and dyspnoea. In ACCLAIM/COPD II, significantly greater proportions of patients with aclidinium versus placebo exceeded the MCID for SGRQ total score up to Week 44 and TDI focal score at Week 12. The lack of a statistically significant difference in SGRQ total score at Week 52 in ACCLAIM/ COPD II may be due to the higher rate of dropouts with placebo versus aclidinium, resulting in a greater proportion of 'healthy survivors' remaining in the placebo arm and reducing the treatment differences observed with aclidinium. In Figure 3, it can be seen that the percentage of placebo-treated patients with an SGRQ improvement $\geq 4$ units increased over time in ACCLAIM/COPD II (24.1$32.8 \%)$, but remained relatively constant in ACCLAIM/ COPD I (36.0-40.0\%).

Aclidinium significantly delayed the time to first moderate or severe exacerbation compared with placebo in ACCLAIM/COPD II, but not in ACCLAIM/COPD I. A possible reason for this variation may be the lower rate of moderate or severe exacerbations in the placebo group in ACCLAIM/COPD I compared with ACCLAIM/COPD II ( 0.46 versus 0.80 events/patient/year, respectively). The placebo exacerbation rate in ACCLAIM/COPD II was similar to that observed in a 1-year study of tiotropium (0.95 events/patient/year) [15] and in the UPLIFT study (0.85 events/patient/year) [21], both of which also reported significant treatment effects on exacerbations. As significant effects on exacerbation are more likely to be shown in populations with frequent exacerbations, the low exacerbation rate in ACCLAIM/COPD I may explain the lack of difference observed between aclidinium and placebo. It should be noted that the study was not powered for exacerbations and the population was not enriched by recruiting patients with a history of exacerbation in the year before entry. The difference in rates also cannot be explained entirely in terms of demographic differences, chiefly a higher proportion of women and a greater smoking history in ACCLAIM/COPD II. While the reasons remain unknown, we postulate that the difference may be related to the fact that exacerbations were defined based on healthcare utilisation (i.e. moderate exacerbation; use of oral corticosteroids and/or 
antibiotics; severe exacerbation; requirement for inpatient hospital treatment); however, differences in healthcare resource utilisation do not appear to have caused any disparity in exacerbation rates in previous studies conducted in different territories.

In accordance with previous Phase I/II studies [6-8,23], aclidinium was safe and well tolerated in these Phase III studies. The percentages of SAEs, cardiovascular events and deaths with aclidinium were either similar or lower than those with placebo. Pooled analyses of safety data from tiotropium trials have indicated that, compared with placebo, tiotropium is associated with an excess risk of dry mouth, urinary retention and arrhythmias $[24,25]$. In the ACCLAIM/COPD studies, the incidence of anticholinergic AEs was similar between the two groups. Although safety analyses of aclidinium have not yet been conducted across multiple studies in a pooled analysis as for tiotropium, the initial evidence suggests that aclidinium may offer a low potential for class-related systemic side effects.

\section{Conclusions}

Treatment with aclidinium $200 \mu \mathrm{g}$ once-daily is safe and improves lung function and symptomatic endpoints in patients with moderate or severe COPD. The clinical relevance of the observed improvements in trough $\mathrm{FEV}_{1}$ is uncertain, as a minimum clinically important difference in trough $\mathrm{FEV}_{1}$ has not yet been established. Some authors have suggested an improvement of about 100$120 \mathrm{~mL}$ as a possible benchmark, but this is expert opinion rather than a validated parameter $[22,26]$. There is evidence that treatment differences in trough $\mathrm{FEV}_{1}$ values have been decreasing in recent trials due to changes in the availability of concomitant medications and baseline patient populations over time [27]. Regulators may consider a change of $5-10 \%$ from baseline $\mathrm{FEV}_{1}$ to be clinically meaningful [22]; assuming a baseline $\mathrm{FEV}_{1}$ of $1.29 \mathrm{~L}$ (the mean across treatment arms in this study), this corresponds to an increase of 64-129 $\mathrm{mL}$. Additional clinical studies of aclidinium are ongoing in patients with moderate to severe COPD to investigate both higher and/or twice-daily dosing that could offer improvements on the efficacy profile compared with the $200 \mu \mathrm{g}$ once-daily dose. In a Phase II, placebo- and active comparator-controlled study, aclidinium $400 \mu \mathrm{g}$ twice-daily provided bronchodilation over 24 hours that was statistically superior and clinically meaningful compared with placebo, and comparable with tiotropium $18 \mu \mathrm{g}$ once-daily [28]. Early Phase III data suggest that aclidinium $200 \mu \mathrm{g}$ and $400 \mu \mathrm{g}$ twicedaily for 12 weeks both provide statistically and clinically significant improvements in lung function compared with placebo [29].

\section{List of abbreviations used}

AE: adverse event; ANCOVA: analysis of covariance; ATS: American Thoracic Society; BDI: Baseline Dyspnoea Index; Cl: confidence interval; COPD: chronic obstructive pulmonary disease; ECG: electrocardiogram; ERS: European Respiratory Society; $\mathrm{FEV}_{1}$ : forced expiratory volume in 1 second; FVC: forced vital capacity; HR: hazard ratio; MCID: minimal clinically important difference; SAE: serious adverse event; SGRQ: St George's Respiratory Questionnaire; TDI: Transitional Dyspnoea Index

\section{Acknowledgements}

We thank all the ACCLAIM/COPD study investigators and Covance Inc. We also thank Dr Sharon Gladwin from Complete Medical Communications, who provided medical writing support. This study was funded by Almirall, S. A., Barcelona, Spain, and Forest Laboratories, Inc, NY, USA

\section{Author details}

'St George's, University of London, London, UK. ${ }^{2}$ Pulmonary and Critical Care Medicine, University of Nebraska Medical Center, Omaha, Nebraska, USA.

${ }^{3}$ Thorax Institute, Hospital Clínic, Barcelona, and CIBER Enfermedades Respiratorias and Fundació Caubet-Cimera, Spain. ${ }^{4}$ Département des Maladies Respiratoires, Université de la Mediterranée AP-HM, Marseille, France. ${ }^{5}$ Pulmonary Research Institute at Hospital Grosshansdorf, Center for Pneumology and Thoracic Surgery, Grosshansdorf, Germany. ${ }^{6}$ Department of Oncology, Haematology and Respiratory Diseases, University of Modena and Reggio Emilia, Modena, Italy. ${ }^{7}$ Division of Pulmonary Disease and Critical Care Medicine, School of Medicine, University of North Carolina, Chapel Hill, North Carolina, USA. ${ }^{8}$ Division of Pulmonology, Department of Medicine, University of Cape Town, Cape Town, South Africa. ${ }^{9}$ Stritch-Loyola School of Medicine, Loyola University, Chicago, Illinois, USA. ${ }^{10}$ Almirall, R\&D Centre, Barcelona, Spain. ${ }^{11}$ Forest Research Institute, New Jersey, USA.

\section{Authors' contributions}

PWJ was the co-ordinating study investigator and SIR, AA, PC, HM, LF, JFD, EDB and NJG were study investigators. All study investigators, CC and EGG made substantial contributions to the conception and design of the study and the interpretation of the study data. RL supervised the statistical analysis. All authors contributed to the development of the manuscript, and read and approved the final version prior to submission.

\section{Competing interests}

PWJ has received fees from a number of pharmaceutical companies, including Almirall, for speaking at meetings and for consulting and participating in advisory board meetings, and has also received support for research from GSK.

SIR has consulted on or participated in advisory boards for numerous pharmaceutical companies, including Almirall, GSK, AstraZeneca, Novartis and Nycomed. He has received industry-sponsored grants from AstraZeneca, Biomarck, Centocor, Mpex, Nabi, Novartis and Otsuka.

AA has received fees for speaking and consultancy, as well as funds for research, from Almirall, GSK, AstraZeneca, Boehringer Ingelheim, Esteve and Chiesi.

PC has received fees for speaking and consultancy from Centocor, AstraZeneca, Chiesi, GSK, Boehringer Ingelheim, Nycomed, Novartis and Almirall, as well as research grants from Schering Plough and Centocor $\mathrm{HM}$ has received funds for research and fees for consulting from a number of pharmaceutical companies.

LF has served as a consultant to, and received lecture fees and grant support from, Nycomed, AstraZeneca, Boehringer Ingelheim, Chiesi, GSK, Merck Sharp \& Dohme and Novartis.

JFD has served on advisory boards for Almirall and Forest Laboratories. EDB has received remuneration for consulting and serving on advisory boards for Almirall, and his institution has received grants for taking part in clinical trials sponsored by Almirall and Forest Laboratories.

NJG has received honoraria for presentations on COPD treatment at meetings sponsored by Almirall and Forest Laboratories, as well as payments for advisory board consultations. His institution has received research grants from Almirall and Forest Laboratories.

$\mathrm{RL}$ and $\mathrm{EGG}$ are employees of Almirall.

CC is an employee of Forest Laboratories, and holds stock and options in the company. 
Received: 22 December 2010 Accepted: 26 April 2011

Published: 26 April 2011

\section{References}

1. Barnes PJ: The role of anticholinergics in chronic obstructive pulmonary disease. Am J Med 2004, 117(Suppl 12A):24S-32S.

2. Rabe KF, Hurd S, Anzueto A, Barnes PJ, Buist SA, Calverley P, Fukuchi Y, Jenkins C, Rodriguez-Roisin R, van Weel C, Zielinski J: Global strategy for the diagnosis, management, and prevention of chronic obstructive pulmonary disease: GOLD executive summary. Am J Respir Crit Care Med 2007, 176:532-555.

3. Gavalda A, Miralpeix M, Ramos I, Otal R, Carreno C, Vinals M, Domenech T, Carcasona C, Reyes B, Vilella D, Gras J, Cortijo J, Morcillo E, Llenas J, Ryder H, Beleta J: Characterization of aclidinium bromide, a novel inhaled muscarinic antagonist, with long duration of action and a favorable pharmacological profile. J Pharmacol Exp Ther 2009, 331:740-751.

4. Cortijo J, Mata M, Milara J, Donet E, Gavalda A, Miralpeix M, Morcillo EJ: Aclidinium inhibits cholinergic and tobacco smoke-induced MUC5AC in human airways. Eur Respir J 2011, 37:244-254.

5. Sentellas S, Ramos I, Alberti J, Salva M, Anton F, Miralpeix M, Beleta J, Gavalda A: Aclidinium bromide, a new, long-acting, inhaled muscarinic antagonist: In vitro plasma inactivation and pharmacological activity of its main metabolites. Eur J Pharm Sci 2010, 39:283-290.

6. Jansat JM, Lamarca R, Garcia GE, Ferrer P: Safety and pharmacokinetics of single doses of aclidinium bromide, a novel long-acting, inhaled antimuscarinic, in healthy subjects. Int I Clin Pharmacol Ther 2009, 47:460-468.

7. Chanez P, Burge PS, Dahl R, Creemers J, Chuchalin A, Lamarca R, Garcia Gil E: Aclidinium bromide provides long-acting bronchodilation in patients with COPD. Pulm Pharmacol Ther 2010, 23:15-21.

8. Joos GF, Schelfhout VJ, Pauwels RA, Kanniess F, Magnussen H, Lamarca R, Jansat JM, Garcia GE: Bronchodilatory effects of aclidinium bromide, a long-acting muscarinic antagonist, in COPD patients. Respir Med 2009, 104:865-872.

9. Quanjer PH, Tammeling GJ, Cotes JE, Pedersen OF, Peslin R, Yernault JC: Lung volumes and forced ventilatory flows. Report Working Party Standardization of Lung Function Tests, European Community for Steel and Coal. Official Statement of the European Respiratory Society. Eur Respir J Suppl 1993, 16:5-40.

10. Magnussen H, Watz H, Zimmermann I, Macht S, Greguletz R, Falques M, Jarreta D, Garcia Gil E: Peak inspiratory flow through the Genuair inhaler in patients with moderate or severe COPD. Respir Med 2009, 103:1832-1837.

11. Miller MR, Hankinson J, Brusasco V, Burgos F, Casaburi R, Coates A, Crapo R, Enright $P$, van der Grinten $C P$, Gustafsson $P$, Jensen $R$, Johnson DC, Maclntyre N, McKay R, Navajas D, Pedersen OF, Pellegrino R, Viegi G, Wanger J: Standardisation of spirometry. Eur Respir J 2005, 26:319-338.

12. Jones PW: St George's Respiratory Questionnaire: MCID. COPD 2005, 2:75-79.

13. Mahler DA, Witek T Jr: The MCID of the transition dyspnea index is a total score of one unit. COPD 2005, 2:99-103.

14. Brusasco V, Hodder R, Miravitlles M, Korducki L, Towse L, Kesten S: Health outcomes following treatment for six months with once daily tiotropium compared with twice daily salmeterol in patients with COPD. Thorax 2003, 58:399-404.

15. Casaburi R, Mahler DA, Jones PW, Wanner A, San PG, ZuWallack RL, Menjoge SS, Serby CW, Witek T Jr: A long-term evaluation of once-daily inhaled tiotropium in chronic obstructive pulmonary disease. Eur Respir J 2002, 19:217-224.

16. Donohue JF, van Noord JA, Bateman ED, Langley SJ, Lee A, Witek TJ Jr, Kesten S, Towse L: A 6-month, placebo-controlled study comparing lung function and health status changes in COPD patients treated with tiotropium or salmeterol. Chest 2002, 122:47-55.

17. Dusser $\mathrm{D}$, Bravo ML, lacono $\mathrm{P}$ : The effect of tiotropium on exacerbations and airflow in patients with COPD. Eur Respir J 2006, 27:547-555.

18. Niewoehner DE, Rice K, Cote C, Paulson D, Cooper JA Jr, Korducki L, Cassino C, Kesten S: Prevention of exacerbations of chronic obstructive pulmonary disease with tiotropium, a once-daily inhaled anticholinergic bronchodilator: a randomized trial. Ann Intern Med 2005, 143:317-326.
19. Tonnel AB, Perez T, Grosbois JM, Verkindre C, Bravo ML, Brun M: Effect of tiotropium on health-related quality of life as a primary efficacy endpoint in COPD. Int J Chron Obstruct Pulmon Dis 2008, 3:301-310

20. Chan CK, Maltais F, Sigouin C, Haddon JM, Ford GT: A randomized controlled trial to assess the efficacy of tiotropium in Canadian patients with chronic obstructive pulmonary disease. Can Respir J 2007, 14:465-472.

21. Tashkin DP, Celli B, Senn S, Burkhart D, Kesten S, Menjoge S, Decramer M: A 4-year trial of tiotropium in chronic obstructive pulmonary disease. $N$ Engl J Med 2008, 359:1543-1554.

22. Cazzola M, MacNee W, Martinez FJ, Rabe KF, Franciosi LG, Barnes PJ, Brusasco V, Burge PS, Calverley PM, Celli BR, Jones PW, Mahler DA, Make B, Miravitlles M, Page CP, Palange P, Parr D, Pistolesi M, Rennard SI, Rutten-van Molken MP, Stockley R, Sullivan SD, Wedzicha JA, Wouters EF: Outcomes for COPD pharmacological trials: from lung function to biomarkers. Eur Respir J 2008, 31:416-469.

23. Schelfhout V, Ferrer P, Jansat JM, Persi F, Garcia Gil E, Pauwels RA, Joos G: Activity of aclidinium bromide, a new long-acting muscarinic antagonist: a phase I study. Br I Clin Pharmacol 2010, 69:458-464.

24. Kesten $S$, Jara M, Wentworth $C$, Lanes S: Pooled clinical trial analysis of tiotropium safety. Chest 2006, 130:1695-1703.

25. Barr RG, Bourbeau J, Camargo CA, Ram FS: Tiotropium for stable chronic obstructive pulmonary disease: a meta-analysis. Thorax 2006, 61:854-862.

26. Donohue JF: Minimal clinically important differences in COPD lung function. COPD 2005, 2:111-124.

27. Donohue JF, Jones P: Changing patterns in long-acting bronchodilator trials in COPD. Int J Chron Obstruct Pulmon Dis 2011, 6:35-45.

28. Magnussen H, Ribera A, Llovera A, Kirsten A, Falques M, Caracta C, Garcia Gil E: Efficacy and safety of aclidinium bromide $400 \mu \mathrm{g}$ BID compared with placebo and tiotropium in patients with moderate to severe COPD [abstract]. Am J Respir Crit Care Med 2010, 181:A4440.

29. Kerwin EM, D'Urzo A, Gelb AF, Lakkis H, Garcia Gil E, Caracta C: Efficacy and safety of twice-daily aclidinium bromide in patients with COPD: results from ACCORD COPD I [abstract]. Chest 2010, 138:469A.

doi:10.1186/1465-9921-12-55

Cite this article as: Jones et al:: Efficacy and safety of once-daily

aclidinium in chronic obstructive pulmonary disease. Respiratory Research 2011 12:55.

\section{Submit your next manuscript to BioMed Central and take full advantage of:}

- Convenient online submission

- Thorough peer review

- No space constraints or color figure charges

- Immediate publication on acceptance

- Inclusion in PubMed, CAS, Scopus and Google Scholar

- Research which is freely available for redistribution

Submit your manuscript at www.biomedcentral.com/submit
C BioMed Central 